\title{
PENGARUH KARAKTERISTIK INDIVIDU DAN GAYA KEPEMIMPINAN TERHADAP KOMITMEN ORGANISASI DENGAN KEPUASAN KERJA SEBAGAI VARIABEL INTERVENING PADA PERSONIL POLRES KOTA LHOKSEUMAWE
}

\author{
Zulfikar $^{1}$, Marbawi $^{2 *}$, Aiyub ${ }^{3}$ \\ ${ }^{123}$ Program Pascasarjana Ilmu Manajemen Universitas Malikussaleh \\ Email: zulfikarpidum@gmail.com, marbawi@unimal.ac.id, aiyub@unimal.ac.id
}

\begin{abstract}
This study aims the influence of Individual Characteristc and transformational leadership on organizational commitment with job satisfaction as intervening variable to the Lhokseumawe police station. For the dependent variable of this study is individual characteristic and transformational leadership, the independent variable is the organizatioan commitment of the police station, Intervening variables are job satisfaction. The population in this study was the Police Personal of the Lhokseumawe District Police which numbered 575, the sampling technique used proportionate stratified random sampling and obtained a sample of 170 respondents who were police officers of the Lhokseumawe police station, the research method used is a quantitative method for data analysis method using Structural Equation Modeling (SEM). The results of this study indicate that, individual characteristic has a significant effect on job satisfaction, transformational leadership has a significant effect on job satisfaction, leadership has not a effect on organizational commitment, transformational leadership has a significant effect on organization commitment, job satisfaction has a significant effect on organizational commitment, individual characteristic has not effect on organizational commitment through job satisfaction as an intervening variable, transformational leadership has a significant effect on organizational commitment through job satisfaction as an intervening variable.
\end{abstract}

\section{Keywords: Individual Characteristic, Transformational Leadership, Job Satisfaction And Organizational Commitment.}

\section{PENDAHULUAN}

Permasalahan keamanan masyarakat saat ini perlu mendapatkan perhatian pemerintah, salah satu aparatur hukum yang bertanggung jawab tentang masalaha keamanan adalah Kepolisian Resor (disingkat Polres) yang merupakan struktur komando Kepolisian Republik Indonesia di daerah kabupaten/kota. Polres bertanggung jawab terhadap penganan di kabupaten atau pemeritahan kota dan membawahi beberapa Polsek (Polisi Sektor) untuk melayani masyrakat dalam persoalan pengamanan daerah. Organisasi Polres Kota Lhokseumawe didirikan untuk mencapai tujuan tertentu yang hanya dapat dilakukan dengan cara kerja sama antar personl Polres Kota Lhokseumawe.

Setiap organisasi Polri akan selalu berusaha untuk meningkatkan kinerja personil, dengan harapan apa yang menjadi tujuan organisasi akan tercapai sesuai visi dan misi organisasi. Berbagai cara akan ditempuh oleh sebuah institusi dalam meningkatkan kinerja dan komitmen organisasi bagi pegawainya. Komitmen organisasi merupakan tindakan pegawai terhadap organisasinya dimana pegawai atau personil yang bekerja pada organisasi memiliki loyalitas, integritas dan komitmennya pada organisasi (Robbin, 2013). Komitmen organisasi yang tinggi sangat diperlukan dalam sebuah organisasi, karena dengan terciptanya komitmen yang tinggi akan mempengaruhi iklim kerja yang profesional.

Selain permasalahan komitmen organisasi, dalam karya ilmiah ini juga mengkaji kepuasan kerja, hal ini perlu diperhatikan. kepuasan kerja adalah sebagai suatu sikap umum seorang individu terhadap pekerjaannya (Robbins, 2013). Lebih lanjut Koesmono (2005) mengemukakan bahwa kepuasan kerja merupakan penilaian, perasaan atau sikap seseorang atau karyawan terhadap pekerjaannya dan berhubungan dengan lingkungan kerja, jenis pekerjaan, kompensasi, hubungan antar teman kerja, hubungan sosial ditempat kerja dan sebagainya. Mangkunegara (2005) 
mengemukakan bahwa ada 2 (dua) faktor yang mempengaruhi kepuasan kerja yaitu faktor yang ada pada diri pegawai dan faktor pekerjaannya.

Karakteristik individu adalah perilaku atau karakter yang ada pada diri seorang karyawan baik yang bersifat positif maupun negatif Sugijanto (2011), karakteristik-karakteristik ini sangat beragam. Robbins (2013) menyatakan bahwa, karakteristik individu merupakan faktor- faktor yang mudah didefinisikan dan tersedia, data yang dapat diperoleh sebagian besar dari informasi yang tersedia dalam berkas personalia seorang pegawai mengemukakan karakteristik individu meliputi usia, jenis kelamin, status perkawinan, banyaknya tanggungan dan masa kerja dalam organisasi. Nimran (2009) menyatakan bahwa untuk memahami perilaku individu, kita perlu mengkaji berbagai karakteristik yang melekat pada setiap individu, adapun berbagai karakteristik individu yang penting adalah (a) ciri biografis yang meliputi, umur, jenis kelamin, status perkawinan, jumlah tanggungan, masa kerja; (b) kepribadian; (c) persepsi yang meliputi: pemberi kesan, sasaran dan situasi; (d) sikap (attitude).

Kepemimpinan transformasional adalah pemimpin yang memotivasi bawahan untuk bekerja demi tercapai sasaran organisasi dan memuaskan kebutuhan mereka pada tingkat lebih tinggi (Burn, 1978), Pemimpin transformasional mengevaluasi kemampuan dan potensi masing-masing bawahan untuk menjalankan suatu tugas/pekerjaan, sekaligus melihat kemungkinan untuk memperluas tanggung jawab dan kewenangan bawahan di masa mendatang (Nugroho, 2006).

Fenomena komitmen organisasi di lapangan mengambarkan bahwa komitmen organisasi personil kepolisian Kota Lhokseumawe dapat diartikan sebagai kelekatan emosi, identifikasi dan keterlibatan individu dengan organisasi serta keinginan untuk tetap menjadi anggota organisasi pada Polres Kota Lhokseumawe, komitmen organisasi pada instusi Polres Kota Lhokseumawe sangat berhubungan dengan tingkat loyalitas dan integritas personil Polres Kota Lhokseumawe, persoalan yang dihadapi personil polres kota Lhokseumawe banyaknya keterlibatan kerja personil pada kegiatan yang bukan menjadi job diskripsinya, hal ini disebabkan banyaknya persoalan keamanan masyarakat yang dilaporkan apa lagi saat ini menjelang pemilu tahun 2019. Oleh karena itu perlunya kepercayaan yang tinggi serta dukungan organisasi terhadap personil Polres Kota Lhokseumawe menjadi suatu hal yang penting bagi tiap-tiap anggota dan institusi.

Disamping itu, kepuasan kerja personil Polres Kota Lhokseumawe berhubungan dengan sifat pekerjaan yang dilakukan sehari yang kadangkala sangat membosankan, membuat sikap personil kurang puas cenderung kurang gairah personil dalam bekerja. Kepuasan kerja berhubungan dengan promosi arti bahwa personil polres yang cenderung dan berkeingan untuk dilakukan promosi tidak terlalu lama pada sebuah unit kerja, untuk meningkatkan komitman dan kinerja personil.

Kepuasan kerja personil polres Kota Lhokseumawe jika dihubungkan dengan tingkat pekerjaan mengandung arti bahwa pegawai yang menduduki tingkat pekerjaan yang lebih tinggi cenderung lebih puas daripada personil yang menduduki pekerjaan yang lebih rendah, karena personil yang tingkat pekerjaannya lebih tinggi menunjukkan kemampuan kerja yang baik dan aktif dalam mengemukakan ide-ide serta kreatif dalam bekerja, kepuasan kerja berhubungan dengan ukuran organisasi perusahaan mengandung arti bahwa besar kecilnya perusahaan dapat mempengaruhi proses komunikasi, koordinasi, dan partisipasi pegawai sehingga dapat mempengaruhi kepuasan kerja karyawan.

Adapun fenomena karakteristik individu mencerminkan bahwa Polres Kota Lhokseumawe memiliki sumber daya organisasi sangat penting bagi kelangsungan kehidupan organisasi dalam rangka mencapai tujuan yang ditetapkan pada Polres Kota Lhokseumawe, sumber daya manusia merupakan modal utama organisasi, sumber daya yang dimaksud adalah sumber daya keuangan, sumber daya waktu, dan sumber daya manusia. Sumber daya keu- angan sangat dibutuhkan, untuk menyelenggarakan kegiatan-kegiatan organisasi dan memberikan insentif kepada anggota organisasi pada Polres Kota Lhokseumawe. Sumber daya waktu dibutuhkan guna melibatkan anggota organisasi dan pimpinan dalam rangka menggerakan organisasi mulai dari perencanaan sampai dengan pengendalian dalam organisasi Polres Kota Lhokseumawe. Sumber daya manusia, tidak perlu dipertanya- kan lagi karena merupakan modal utama organisasi karena merupakan otaknya manajemen dalam menjalankan tugas pokok dan fungsinya pada instutusi polres kota Lhokseumawe, disisi lain karakteristik individu dalam institusi Polres Kota Lhokseumawe memiliki hubungan dengan kepemimpinan.

Begitu juga dalam hal gaya kepemimpinan, seorang kapolres harus cerdas dan inovatif dalam mengarahkan personil aparatus untuk meningkarkan komitmen dan kepuasan kerja pada Polres Kota 
Lhokseumawe, selain itu dengan gaya kepemimpinan juga dapat meningkatkan kinerja aparatur karena banyak personil polres yang telah memahami akan tugas pokok dan fungsi yang berlaku di Polres Kota Lhokseumawe, aparatur diberikan inovasi dalam bekerja, memiliki kecepatan kerja saat bertugas, adanya keahlian, keakuratan saat mengerjakan tugas serta bekerjasama sesama personil polri di Polres Kota Lhokseumawe, hal inilah yang membuat komitmen personil meningkat, pada Polres Kota Lhokseumawe. Berdasarkan permasalahan diatas, maka peneliti tertarik melakukan penelitian dengan judul "Pengaruh Karakteristik Individu dan Gaya Kepemimpinan Terhadap Komitmen Organisasi Dengan Kepuasan Kerja Sebagai Variabel Intervening Pada Polres Kota Lhokseumawe".

\section{TINJAUAN PUSTAKA}

\section{Komitmen Organisasi}

Komitmen organisasi adalah sikap yang merefleksikan loyalitas karyawan pada organisasi dan proses berkelanjutan dimana anggota organisasi mengekresikan perhatiannya terhadap organisasi dan keberhasilan serta kemajuan yang berkelanjutan (Luthans, 2011).

Komitmen organisasi mengacu kepada beberapa indikator menurut Allen \& Meyer (1993) yaitu emosional, keterlibatan kerja, loyalitas, kebutuhan, tanggung jawab dan kesadaran.

\section{Kepuasan Kerja}

Kepuasan kerja adalah perasaan positif tentang pekerjaan seseorang yang merupakan hasil dari evaluasi karakteristik-karakteristiknya (Robbins, 2013).

Kepuasan kerja mengacu kepada beberapa indikator menurut Luthans (2011) dan Siahaan (2017) yaitu sifat pekerjaan, rekan kerja, supervisor, gaji/upah dan promosi.

\section{Karakteristik Individu}

Karakteristik Individu merupakan ciri-ciri khusus, sifat-sifat kejiwaan, akhlak atau budi pekerti yang dimiliki seseorang yang membedakannya dengan orang lain (Rivai, 2006).

Karakteristik Individu mengacu kepada beberapa indikator menurut Marbawi (2018) yaitu kemampuan, sikap, nilai, kepribadian dan pembelajaran.

\section{Kepemimpinan Transformasional}

Kepemimpinan Transformasional merupakan pemimpin yang mempunyai kekuatan untuk mempengaruhi bawahan dengan cara-cara tertentu (Bass, dalam Yukl, 2013).

Kepemimpinan Transformasional mengacu kepada beberapa indikator menurut Robbins (2013) yaitu menginspirasi, memiliki kharisma, memotivasi, cerdas, inovasi dan perhatian.

Berdasarkan uraian diatas maka kerangka konseptual dalam penelitian ini seperti tergambar pada Gambar 1 berikut ini:

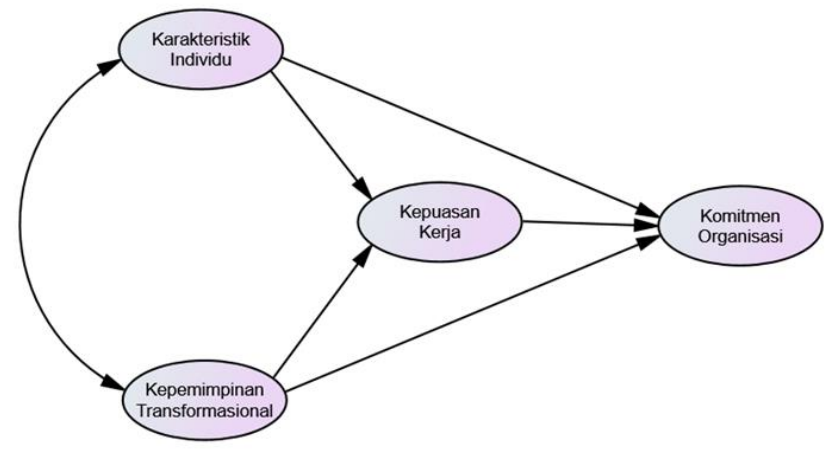

\section{Gambar 1 Kerangka Konseptual}

\section{Hipotesis}


Berdasarkan kerangkan konsep penelitian, maka dapat dirumuskan 7 (tujuh) pernyataan hipotesis sebagai berikut:

H1: Karakteristik individu mempengaruhi secara positif dan signifikan terhadap kepuasan kerja pegawai pada Polres Kota Lhokseumawe.

H2: Kepemimpinan transformasional mempengaruhi secara positif dan signifikan terhadap kepuasan kerja pegawai pada Polres Kota Lhokseumawe.

H3: Karakteristik individu mempengaruhi secara positif dan signifikan terhadap komitmen organisasi pegawai Polres Kota Lhokseumawe.

H4 : Kepemimpinan transformasional mempengaruhi secara positif dan signifikan terhadap komitmen organisasi pegawai Polres Kota Lhokseumawe.

H5: Kepuasan kerja mempengaruhi secara positif dan signifikan terhadap komitmen organisasi pegawai Polres Kota Lhokseumawe.

H6: Kepuasan kerja memediasi hubungan karakteristik individu terhadap komitmen organisasi pegawai Polres Kota Lhokseumawe.

H7: Kepuasan kerja memediasi hubungan kepemimpinan transformasional terhadap komitmen organisasi pegawai pada Polres Kota Lhokseumawe.

\section{Metode Penelitian}

Variabel bebas dalam penelitian ini adalah karakteristik individu dan kepemimpinan transformasional. Selanjutnya kepuasan kerja sebagai mediator, sedangkan variabel terikatnya adalah komitmen organisasi. Tipe penelitian adalah pernyataan dengan menggunakan kuesioner sebagai alat untuk mengambil data. Instrumen penelitian menggunakan skala Linkert yang telah dimodifikasi 1-5. Populasi dalam penelitian ini adalah personil Polres Kota Lhokseumawe berjumlah 575. Teknik pengambilan sampel menggunakan proportionate stratified random sampling dan diperoleh sampel sebanyak 170 responden. Teknik analisis menggunakan Structural Equation Model (SEM) dengan menggunakan program komputer SPSS 16.0 dan Amos. Uji validitas instrumen menggunakan Confirmatory Faktor Analysis (CFA) masing-masing kontruk yaitu dengan melihat nilai Loading Factor masing-masing indikator dan didapat hasil setiap butir peryataan memiliki nilai $>0,6$. Adapun uji reabilitas dengan menggunakan rumus sebagai berikut:

$$
\text { Construct Reliability }=\frac{\left(\sum \text { std.loading }\right)^{2}}{\left(\sum \text { std.loading }\right)^{2}+\sum_{e i}}
$$

Sementara ekstrak varian dapat dihitung dengan rumus sebagai berikut:

$$
\text { Variance Extracted }=\frac{\sum \text { std.loading }}{2}
$$

\section{Hasil Penelitian dan Pembahasan}

Hasil analisis full model 1 (model awal) dengan menggunakan analisis SEM ditunjukkan pada gambar 2 .

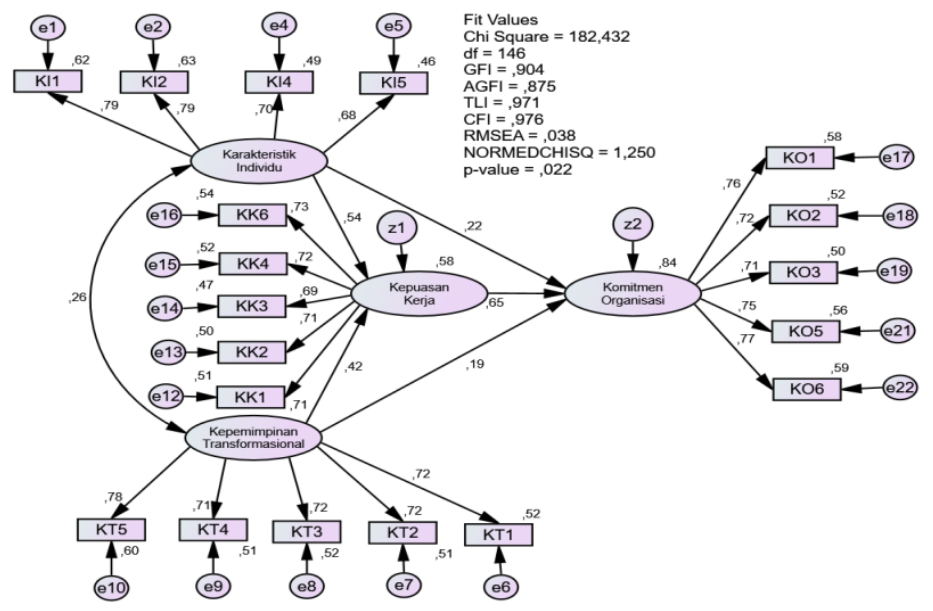

Gambar 2 CFA Konstruk Full Model sebelum Dimodifikasi 
Selanjutnya uji kesesuaian model dapat dilihat pada Tabel 1 berikut:

Tabel 1

Uji Indeks Kesesuaian Structural Equation Model Full Model sebelum Modifikasi

\begin{tabular}{llcc}
\hline Goodness of Fit Index & Cut-off Value & Hasil Analisis & Evaluasi Model \\
\hline $\mathrm{X}^{2}$-Chi-Square & Diharapkan Kecil & 182.432 & Baik \\
Probability & $\geq 0.05$ & 0.022 & Marginal \\
GFI & $\geq 0.90$ & 0.904 & Baik \\
AGFI & $\geq 0.90$ & 0.875 & Marginal \\
CFI & $\geq 0.95$ & 0.976 & Baik \\
TLI & $\geq 0.95$ & 0.971 & Baik \\
CMIN/DF & $\leq 2$ & 1.250 & Baik \\
RMSEA & $\leq 0.08$ & 0.022 & Baik \\
\hline
\end{tabular}

Berdasarkan table 1 di atas memperlihatkan hasil akhir analisis confirmatory factor analysis full model. Secara umum semua kontruk yang digunakan dalam membentuk model penelitian ini, baik pada analisis konfirmatori (CFA), nilai regresi antar kontruk maupun uji goodness of fit yang terdiri dari X2-Chi-Square, GFI, CFI, TLI, CMIN/DF, dan RMSEA sudah memenuhi kriteria yang disyaratkan kecuali Probability dan AGFI yang berada pada nilai belum baik, oleh karena itu perlu dilakukan modifikasi.

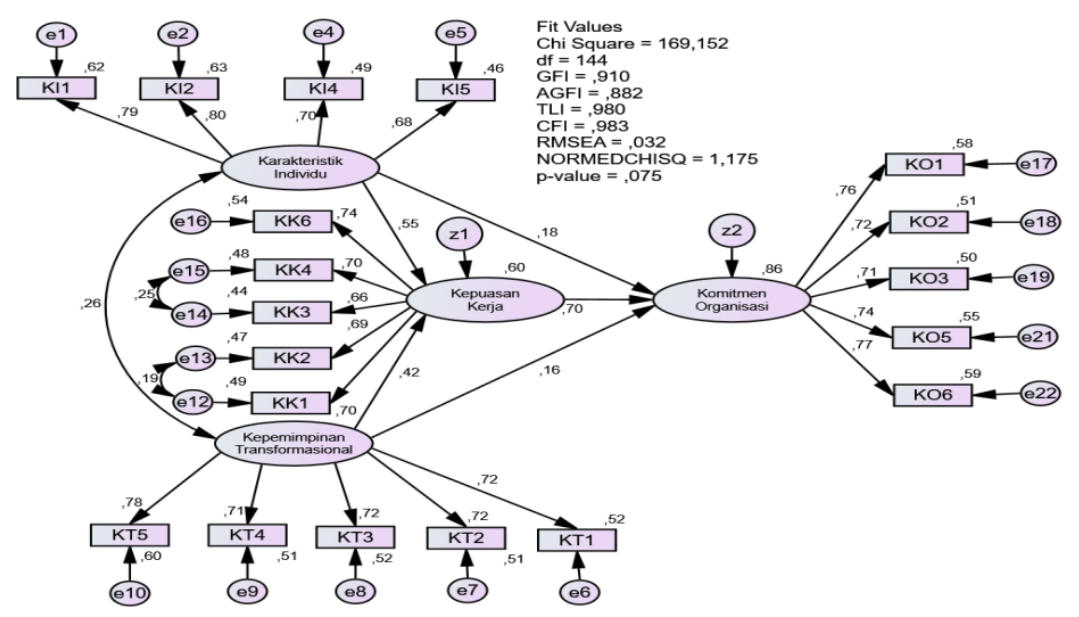

\section{Gambar 3 CFA Konstruk Full Model setelah Dimodifikasi}

Selanjutnya uji kesesuaian model dapat dilihat pada Tabel 2 berikut:

Tabel 2

Uji Indeks Kesesuaian Structural Equation Model Full Model setelah Modifikasi

\begin{tabular}{llcc}
\hline Goodness of Fit Index & Cut-off Value & Hasil Analisis & Evaluasi Model \\
\hline X $^{2}$-Chi-Square & Diharapkan Kecil & 169,152 & Baik \\
Probability & $\geq 0.05$ & 0.075 & Baik \\
GFI & $\geq 0.90$ & 0.910 & Baik \\
AGFI & $\geq 0.90$ & 0.882 & Marginal \\
CFI & $\geq 0.95$ & 0.980 & Baik \\
TLI & $\geq 0.95$ & 0.980 & Baik \\
CMIN/DF & $\leq 2$ & 1.175 & Baik \\
RMSEA & $\leq 0.08$ & 0.075 & Baik \\
\hline
\end{tabular}


Berdasarkan gambar 3 dan tabel 2 di atas memperlihatkan hasil akhir analisis confirmatory factor analysis full model. Secara umum semua kontruk yang digunakan dalam membentuk model penelitian ini, baik pada analisis konfirmatori (CFA), nilai regresi antar kontruk maupun uji goodness of fit yang terdiri dari CDMIN/DF, probability, TLI, CFI GFI dan RMSEA, telah memenuhi kriteria yang disyaratkan kecuali AGFI yang berada pada nilai hampir baik, maka model dapat disimpulkan telah fit dan mendukung data, namun terdapat nilai marginal AGFI namun sudah dapat diterima dikarenakan nilai probability sudah di atas 0.05 , sehingga model sudah dapat diterima sehingga model layak digunakan dalam penelitian ini.

Untuk melihat seberapa besar pengaruh langsung, tidak langsung dan pengaruh total ditampilkan dalam Tabel 3:

Tabel 3

Pengujian Pengaruh Langsung, Tidak Langsung dan Pengaruh Total

\begin{tabular}{lcccc}
\hline & $\begin{array}{c}\text { Kepemimpinan } \\
\text { Transformasional }\end{array}$ & $\begin{array}{c}\text { Karakteristik } \\
\text { Individu }\end{array}$ & $\begin{array}{c}\text { Kepuasan } \\
\text { Kerja }\end{array}$ & $\begin{array}{c}\text { Komitmen } \\
\text { Organisasi }\end{array}$ \\
\hline $\begin{array}{l}\text { Direct Effect } \\
\text { Kepuasan Kerja }\end{array}$ & 0,424 & 0,546 & 0,000 & 0,000 \\
$\begin{array}{l}\text { Kom. Organisasi } \\
\text { Indirect Effect }\end{array}$ & 0,160 & 0,181 & 0,702 & 0,000 \\
$\begin{array}{l}\text { Kepuasan Kerja } \\
\text { Kom. Organisasi }\end{array}$ & 0,000 & 0,000 & 0,000 & 0,000 \\
Total Effect & 0,298 & 0,384 & 0,000 & 0,000 \\
Kepuasan Kerja & 0,424 & & & \\
Kom. Organisasi & 0,458 & 0,546 & 0,000 & 0,000 \\
\hline
\end{tabular}

Hasil pengujian efek memediasi (intervening) hubungan variabel karakteristik individu dengan variabel komitmen organisasi yang dimediasi oleh variable kepuasa kerja ditampilkan dalam bentuk Gambar 4:

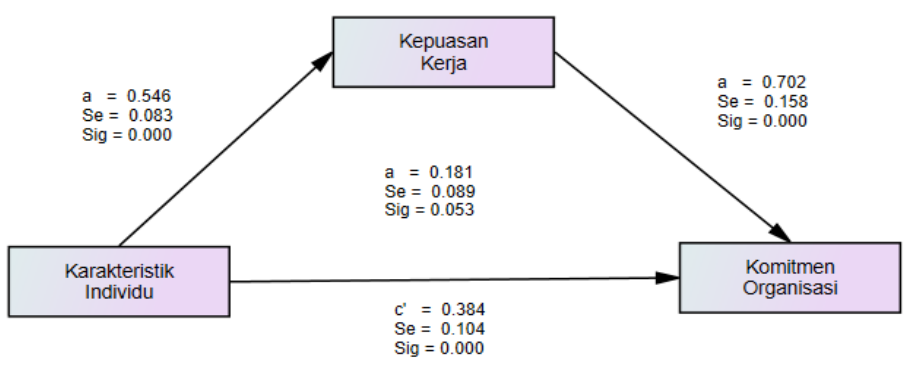

\section{Gambar 4. Hasil Uji Efek Mediasi}

Gambar 4 dapat dijelaskan bahwa koefesien jalur A, jalur B signifikan dan jalur C tidak signifikan, sedangkan jalur $\mathrm{C}^{\prime}$ juga signifikan. Karena probabilitas jalur $\mathrm{C}$ tidak signifikan, sehingga dapat disimpulkan kepuasan kerja tidak memenuhi syarat berfungsi sebagai variable mediasi.

Hasil pengujian efek memediasi (intervening) hubungan variabel kepemimpinan transformasional dengan variabel komitmen organisasi yang dimediasi oleh variabel kepuasan kerja ditampilkan dalam bentuk Gambar 5:

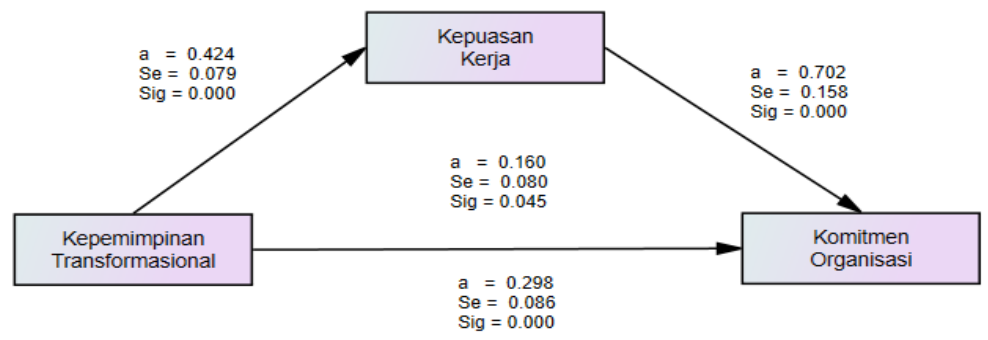

\section{Gambar 5. Hasil Uji Efek Mediasi}


Gambar 5 dapat dijelaskan bahwa koefesien jalur A, jalur B signifikan dan jalur C signifikan, sedangkan jalur $\mathrm{C}^{\prime}$ juga signifikan. Karena probabilitas jalur $\mathrm{C}^{\prime}$ signifikan, sehingga dapat disimpulkan tidak terjadi hubungan parsial mediation dengan kata lain variabel kepemimpinan transformasional (variabel independen) mampu mempengaruhi secara signifikan terhadap komitmen organisasi (variabel dependen) melalui variabel mediator yaitu kepuasan kerja sehingga hipotesis ketujuh (H7) diterima.

Tabel 4

\section{Hasil Uji Hipotesis}

\begin{tabular}{llccccc}
\hline No & \multicolumn{1}{c}{ Pernyataan Hipotesis } & Est. & $S . E$. & $C . R$. & $P$ & Ket \\
\hline $\mathbf{1}$ & $\begin{array}{l}\text { Karakteristik individu berpengaruh positif dan } \\
\text { signifikan terhadap kepuasan kerja }\end{array}$ & 0.470 & 0.083 & 5.676 & 0.000 & $\begin{array}{c}\text { Hipotesis } \\
\text { Diterima }\end{array}$ \\
$\mathbf{2}$ & $\begin{array}{l}\text { Kepemimpinan transformasional berpengaruh } \\
\text { positif dan signifikan terhadap kepuasan kerja }\end{array}$ & 0.386 & 0.424 & 4.894 & 0.000 & $\begin{array}{c}\text { Hipotesis } \\
\text { Diterima }\end{array}$ \\
$\mathbf{3}$ & $\begin{array}{l}\text { Karakteristik individu berpengaruh positif dan } \\
\text { signifikan terhadap komitmen organisasi }\end{array}$ & 0.173 & 0.089 & 1.931 & 0.053 & $\begin{array}{c}\text { Hipotesis } \\
\text { Ditolak }\end{array}$ \\
$\mathbf{4}$ & $\begin{array}{l}\text { Kepemimpinan transformasional berpengaruh } \\
\text { positif dan signifikan terhadap komitmen } \\
\text { organisasi }\end{array}$ & 0.161 & 0.80 & 2.006 & 0.045 & $\begin{array}{c}\text { Hipotesis } \\
\text { Diterima }\end{array}$ \\
$\mathbf{5}$ & $\begin{array}{l}\text { Kepuasan kerja berpengaruh positif dan } \\
\text { signifikan terhadap Komitmen organisasi }\end{array}$ & 0.780 & 0.158 & 4.948 & 0.000 & $\begin{array}{c}\text { Hipotesis } \\
\text { Diterima }\end{array}$ \\
$\mathbf{6}$ & $\begin{array}{l}\text { Kepuasan kerja memediasi secara parsial } \\
\text { pengaruh karakteristik individu terhadap } \\
\text { Komitmen organisasi }\end{array}$ & 0.384 & 0.104 & 3.681 & 0.000 & $\begin{array}{c}\text { Hipotesis } \\
\text { Ditolak }\end{array}$ \\
$\mathbf{7}$ & $\begin{array}{l}\text { Kepuasan kerja memediasi secara parsial } \\
\text { pengaruh kepemimpinan transformasional } \\
\text { terhadap Komitmen organisasi }\end{array}$ & 0.298 & 0.086 & 3.422 & 0.000 & $\begin{array}{l}\text { Hipotesis } \\
\text { Diterima }\end{array}$ \\
\hline
\end{tabular}

\section{Implikasi Penelitian}

Penelitian dilaksanakan harus dapat memberikan kontribusi atau implikasi baik secara teoritis untuk pengembangan ilmu pengetahuan maupun secara praktik atau kebijakan manajerial. Penelitian ini telah berupaya memberikan dua kontribuasi yaitu kontribusi secara teoritis dan kontribusi secara praktik.

\section{Implikasi Secara Teoritis}

Penelitian ini menghasilkan beberapa implikasi secara teoritis yaitu sebagai berikut:

1. Hasil penelitian ini menunjukkan bahwa variabel karakteristik individu berpengaruh positif dan signifikan terhadap kepuasan kerja dan komitmen organisasi pada suatu institusi, hasil ini telah memperkuat dan menambah jumlah literatur ilmiah dalam lingkup teori manajemen SDM dan perilaku organisasi sehubungan dengan hasil analisi ini dan pengaruh variabel karakteristik individu terhadap kepuasan kerja dan komitmen organisasi didukung oleh banyak peneliti sebelumnya.

2. Hasil penelitian ini menunjukkan bahwa variabel kepemimpinan transformasional berpengaruh positif dan signifikan terhadap kepuasan kerja dan komitmen organisasi, hasil ini telah memperkuat dan menambah jumlah literatur ilmiah dalam lingkup teori manajemenSDM dan perilaku organisasi sehubungan dengan pengaruh variabel kepemimpinan transformasional terhadap kepuasan kerja dan komitmen organisasi.

3. Hasil penelitian ini menunjukkan bahwa variabel kepuasan kerja memediasi hubungan kepemimpinan transformasional terhadap komitmen organisasi. Hasil ini telah memperkuat dan menambah jumlah literatur ilmiah dalam menganalisis variable mediasi dalam suatu penelitian.

\section{Implikasi Secara Praktis}

1. Dari hasil penelitian ini ditemukan bahwa variabel karakteristik individu dan kepemimpinan transformasional berpengaruh positif dan signifikan terhadap kepuasan kerja dan komitmen organisasi personil Polres Kota Lhokseumawe, hasil penelitian ini dapat menjadi acuan instansi dalam implementasi karakteristik individu dan gaya kepemimpinan transformasional dan 
kepuasan kerja personil personil Polres Kota Lhokseumawe, sehingga karakteristik individu dan gaya kepemimpinan ini terus dipertahankan untuk mendukung komitmen organisasi dan kinerja. Hal ini berimplikasikan peningkatan kinerja, kepuasan kerja dan komitmen yang tinggi personil untuk organisasi personil Polres Kota Lhokseumawe.

2. Dari hasil penelitian ini ditemukan bahwa variabel karakteristik individu memiliki pengaruh dominan terhadap kepuasan kerja personil Polres Kota Lhokseumawe, hasil penelitian ini dapat menjadi acuan institusi dalam meningkatkan kepuasan kerja personil dalam rangka peningkatan kepuasan kerja personil Polres Kota Lhokseumawe, sehingga kepuasan kerja personil terus dipertahankan dan komitmen organisasi terus diberikan atasan kepada personil sehingga komitmen organisasi personil meningkat. Hal ini berimplikasikan peningkatan kinerja personil dan kepuasan kerja personil Polres Kota Lhokseumawe.

\section{DAFTAR REFERENSI}

Allen, N. J. \& Meyer, J. P. 1993. The Measurement and Antecendents of Affective, Continuance, and Normative Commitment to The Organization. Journal of Occupatinal Psychology, vol: 63, pp. $1-18$.

Burns, J. MacGregor. 1978. Leadership. New York: Harper \& Row.

Koesmono, H. Teman (2005) Pengaruh Budaya Organisasi Terhadap Motivasi dan Kepuasan Kerja serta Kinerja Karyawan Pada Sub Sektor Industri Pengolahan Kayu Skala Menengah Di Jawa Timur. JURNAL MANAJEMEN \& KEWIRAUSAHAAN, VOL. 7, NO. 2, SEPTEMBER 2005: 171-188.

Luthans, Fred. 2011. Organizational Behavior : An Evidence-Based Approach. New York: McGrawHill.

Mangkunegara, A.A Anwar Prabu, (2005). Manajemen Sumber daya Manusia Perusahaan. Bandung : PT Remaja Rosdakarya

Marbawi (2018) Marbawi, (2017). The influence of individual characteristics and transformational leadership on job satisfaction and performance of employee in Bank Aceh Syaria, Proceding EBIC Universitas Sumatera Utara.

Riva'i. Veithzal. 2006. Performance Appraisal. Jakarta: PT. Raja Grafindo Persada.

Robbins, Stephen P dan Timothy A. Judge., (2013). Organizational Behavior, Prentice Hall Inc., New Jersey.

Siahaan, Elisabet. (2017) The Antecedent of employee's performance and the influence on employee job satisfaction in Banking Service in Indonesia. Bank and Bank System, Vol 12 issue 4.

Yukl, Gary (2013) Leadership In Organizations. Penerbit: Pearson 